\title{
Justitia Holthuis, 1946 (Crustacea, Decapoda, Palinuridea) from the Middle Eocene of Verona and Vicenza (northern Italy)
}

\author{
Alessandro Garassino ${ }^{1}$ \& Antonio De Angeli ${ }^{2}$ \\ ${ }^{1}$ Dipartimento di Paleontologia degli Invertebrati, Museo civico di Storia naturale, C.so Venezia 55 , \\ I-20121 Milano, Italy; ${ }^{2}$ Associazione Amici del Museo ëG. Zannatoi, Piazza Marconi, 15, I-36075 \\ Montecchio Maggiore (Vicenza), Italy
}

Keywords: Crustacea, Decapoda, Eocene, Italy

\begin{abstract}
Recently, Beschin et al. (2001) have described two specimens of palinurids, discovered at Chiampo ("Albanello" quarry, Vicenza, northern Italy). Preserved three dimensionally, these were collected from limestones of Lutetian (middle Eocene) age. The peculiar ornament of the dorsal carapace surface, consisting of imbricate scales in the cephalic region and parallel grooves in the branchial and cardiac regions, has allowed these to be ascribed to Justitia Holthuis, 1946, as a new species (J.vicetina Beschin et al., 2001), in the infraorder Palinuridea Latreille, 1802. This represents the first fossil record of this genus.
\end{abstract}

\section{Introduction}

This recent discovery in the Vicenza area triggered a comparative study with material from Monte Bolca, which had never been described in any morphological detail. Palinurids from Veronese outcrops were recorded for the first time by Desmarest (1822), who assigned them to Palinurus Weber, 1795. The description of palinurids from Monte Bolca dates back to the second half of the nineteenth century, when one specimen in Anchille de Zignois private collection was recorded by de Zigno himself as Palinurus desmaresti, making reference to Desmarest's earlier paper. However, de Zigno provided neither a description of the morphology of this taxon, nor an illustration. Subsequent to this first report, other palinurids were discovered during excavations in the second half of the nineteenth century. It took until 1975 for a brief morphological description to appear (Secretan, 1975), although a number of authors made reference to these specimens in their papers and correspondence. Garassino \& Novati
(2001) later revised original nineteenth century samples (Museo di Storia naturale di Verona, Museo Geologico e Paleontologico dell'Università di $\mathrm{Pa}$ dova), and confirmed, on the basis of carapace ornament and the presence of three transverse and parallel grooves on abdominal somites, previous assignment to the extant genus Justitia, accepting $J_{\text {. desmaresti (Massalongo, 1854) as the valid name }}$ for the Monte Bolca species.

\section{The genus Justitia}

Currently, Justitia is represented in the fossil record only by these two species, $J_{x}$ vicetina and $J_{x}$ desmaresti, which differ in the ornament of the dorsal carapace surface, the presence or absence of transverse and parallel grooves on the abdominal somites (Fig. 1), and stratigraphic age. A study of calcareous nannoplankton from Monte Bolca by Medizza (1975),showed a late Ypresian-early Lutetian age, while at "Albanello" quarry strata of middle Lutetian age are exposed.

The dorsal carapace ornament of transverse ridges in the two fossil species of Justitia also occurs in other Cenozoic decapod crustaceans of Veneto, e.g., Lophoranina Fabiani, 1910, Lovarina Beschin et al., 1991 and Eopalicus Beschĩn et al., 1996. This typical ornament was interpreted by Savazzi (1981) to help the animal construct its burrows. Poupin (1994) observed that some extant palinurids prefer . muddy bottoms in which they are able to hide themselves or excavate borrows. 


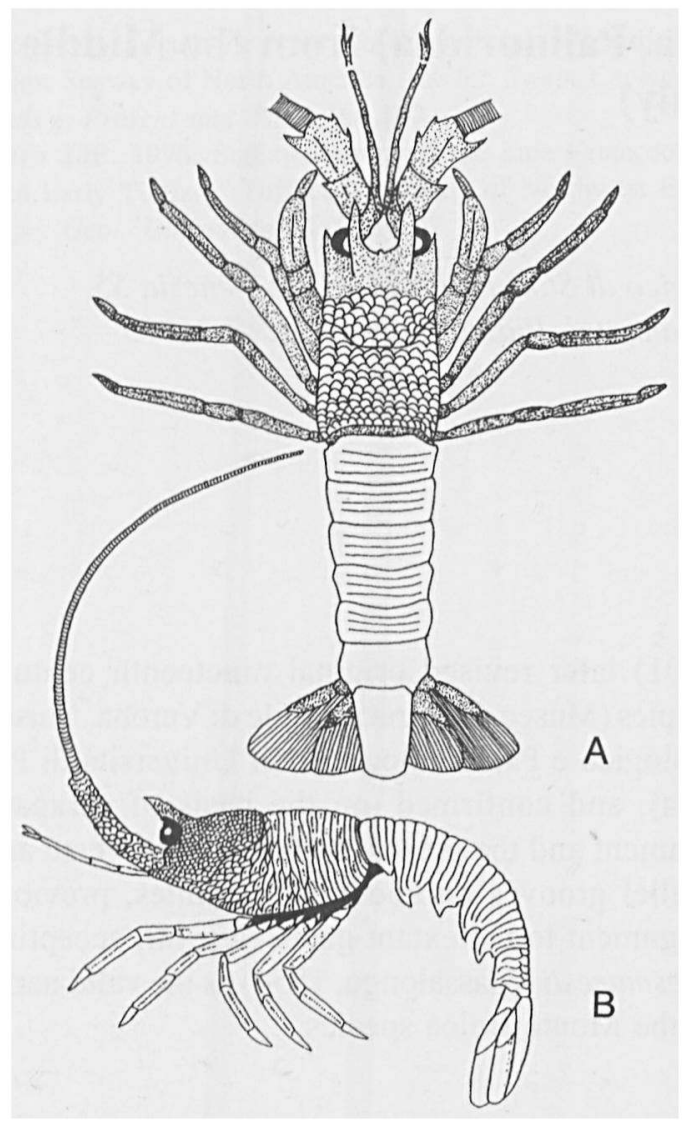

Fig. I. Justitia desmaresti (Massalongo, 1854) (A) and Justitia vicetina Beschin, de Angeli \& Garassino, 2001 (B) compared.

These fossils species demonstrate that the genus Justitia had its origins in Cenozoic time, and thus resembles other fossil palinurids assigned to $\mathrm{Pa}$ - linurus and Palaeopalinurus Bachmayer, 1954. The geographic distribution of modern species of Justitia, i.e., the warm seas of the Indo-Pacific and western Atlantic, further confirms the observation of some authors that there must have been close ties between the rich and diverse Eocene faunas from Veneto (northern Italy) and those of tropical seas.

\section{References}

Beschin C, de Angeli A, Garassino A. 2001. Justitia vicetina sp. nov. (Crustacea, Decapoda) dellí Eocene di Chiampo (Vicenza, Italia settentrionale). Studi Trent. Sci. nat. Acta geol. 76 (1999): 89-97.

Desmarest AG. 1822. Histoire naturelle des Crustacés fossiles. Paris: F.G. Levrault.

Garassino A, Novati M. 2001. Justitia desmaresti (Massalongo, 1854) (Crustacea, Decapoda) from the Lutetian (Middle Eocene) of Monte Bolca (Verona, N Italy). Atti Soc, it. Sci. nat. Mus. civ. Storia nat. Milano 141: 251268.

Medizza F. 1975. Il nannoplancton calcareo della Pesciaia di Bolca (M.ti Lessini). Miscell. Paleont. Mus. civ. Storia nat. Verona 2: 433-444.

Poupin J. 1994. The genus Justitia Holthuis, 1946, with the description of $J$. chani and $J$. vericeli spp. nov. (Crustacea: Decapoda: Palinuridea). Jour. Taiwan Mus. 47: 37-56.

Savazzi E. 1981. Functional morphology of the cuticular terraces in Ranina (Lophoranina) (brachyuran decapods; Eocene of N. Italy). N. Jb. Geol. Paläont. Abh. 162: 231243.

Secretan S. 1975. Les Crustacés du Monte Bolca. Studi e Ricerche sui giacimenti Terziari di Bolca. Miscell. Paleont. Mus. civ. Storia nat. Verona 2: 315-388.

Received: 2 March 2003 